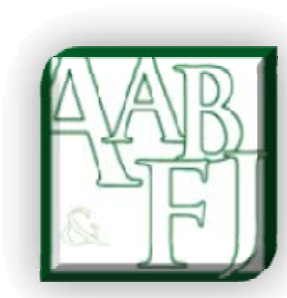

\title{
Corporate Social and Environmental Responsibility in an Emerging Economy: Through the Lens of Legitimacy Theory
}

\author{
Asit Bhattacharyya ${ }^{1}$
}

\begin{abstract}
Efforts to promote Corporate Social and Environmental Responsibility (CSER) require an understanding of stakeholder attitudes toward enhanced responsibility. However, little is known about current attitudes on this subject, or the determinants of these attitudes. This study presents a survey of the attitudes of Indian managers, toward 18 social and 16 key contemporary environmental management issues. The findings indicate that respondents are concerned about a range of issues surrounding social responsibility. With respect to environmental responsibilities, Indian respondents were also strong in their support, and identified a select few issues to be more important over other environmental factors. Results indicated a positive attitude of Indian managers towards CSER. Confirmatory factor analysis (CFA) confirmed three distinct social and environmental factors for the respondents and provided a model of managerial attitudes towards CSER.
\end{abstract}

JEL Classification: M48, N55, Q20

Keywords: CSER, social responsibility, Emerging economy, Legitimacy theory, India.

\footnotetext{
${ }^{1}$ The University of Newcastle, asit.bhatta@newcastle.edu.au
} 


\section{Introduction}

Corporate social and environmental responsibility (CSER) research gained increasing significance, particularly among academic accountants in Western countries (Adams \& Kuasirikun, 2004). Whilst there has been an increase in CSER research, most studies have focused on Western countries (Adams \& Kuasirikun, 2004). Relatively few attempts have been made to research CSER in the non-western and especially Asian context (Kuasirikun, 2005). Scant published research work (except Belal \& Owen, 2007; Islam \& Deegan, 2008; Islam \& Dellaportas, 2011) is available in the area of managerial attitudes, purely from a south-Asian emerging economy perspective. Fukukawa, Shafer \& Lee (2007) suggested that future studies should assess support for SER, and the determinants of such support among stakeholders from a diverse group of nations. Cummings (2008) suggested that future research could undertake further empirical work across geographical locations, and explore in more detail the underlying determinants that shape environmental beliefs and attitudes.

This study is motivated by the urge to obtain a better understanding of managerial attitudes toward CSER within emerging south Asian economies, particularly Indian managerial attitudes. It is important in gaining an understanding of current and potentially future Indian managerial attitudes. Understanding Indian CSER practice is critical because India is one of the important emerging economies in Asia in terms of economic growth, with significant urbanisation, a large populace, and a growing presence in the global market. Despite these factors, Indian environmental practices are far behind those found in developed economies (Balasubramanian, Kimber \& Siemensma 2005). This study will help in understanding Indian CSER practices. CSER information is crucial to various Indian government organisations and foreign investors. Embedding social and environmental criteria within the supply chain of companies, including its procurement practices, and adopting international quality standards and benchmarks, are becoming essential in order to attract foreign direct investment, and export goods to countries and markets which require sustainable production practices. In future this will require Indian government authorities to both enact and enforce regulations that improve social and environmental conditions to a level ideally on par with their developed counterparts. Foreign investors may also use environmental information to gauge Indian operating standards, in order to establish and operate sustainable businesses in India.

Some emerging economies are confronted with the widespread problem of poverty, human rights violations, corruption, inequalities and social exploitation. Pachauri (2006) argued that organisations operating within emerging economies have a responsibility to address some of these problems. By holding business organisations to account, Belal and Momin (2009) believed CSER has the potential to promote equality, social justice, transparency and responsibility. Studying attitudes will enable a better understanding of the relationship (if any) among social and environmental factors, such as culture, ethics, education, law and its enforcement, and the attitude towards environmental management, and whether those attitudes vary across different industries (Thorne \& Saunders, 2002). This study contributes to the little researched area of managerial attitude towards CSER and does so in Indian context.

The objective of this paper is twofold.

(1) To examine the Indian managerial attitudes toward CSER and assess their support for social and environmental responsibility.

(2) To explore the underlying factors those may be responsible to shape Indian managerial attitudes. 
Selected contemporary social and environmental issues have been used to determine respondent's attitudes and support. Principal component analysis (PCA) is used to explore the underlying dimension or factors for social and environmental responsibility. A confirmatory factor analysis (CFA) was also undertaken to confirm the social and environmental factors in the study. The paper used organisational legitimacy theory to discuss managerial attitudes with regard to maintaining legitimacy as defined by Suchman (1995). Using a sample of 168 randomly chosen, publicly listed, environmentally sensitive Chemical, Industrial Engineering and Pharmaceutical and Biotech companies, this study investigates managerial attitudes towards CSER with the purpose of better understanding of Indian managerial attitudes toward CSER.

The remainder of the paper is organized as follows: Section 2 presents theoretical framework of the study describing how responsibility and legitimacy are defined with reference to companies. Section 3 reviews relevant prior literature. Section 4 discusses research design issues by presenting methodology, sample and data. Section 5 presents descriptive and empirical results, and section 6 discusses the findings and concludes the paper.

\section{Theoretical Framework}

While there is no generally accepted theory for explaining CSER practices, recent research in the CSR literature has relied heavily on legitimacy theory (for example, Branco \& Rodrigues, 2008; Claasen \& Roloff, 2012). According to Gray (1995a), legitimacy theory has an advantage over other theories in that it provides disclosing strategies that organisations may adopt to legitimate their existence that may be empirically tested. Legitimacy theory explains the association of accountability with the society from an organisation's perspective. An organisation will voluntarily report on activities if management perceives that the particular information is demanded by the societies in which it operates (De Villiers \& Van Staden, 2006).

\section{Social Responsibility and Legitimacy}

\section{Social responsibility}

Carroll (1999) stated the question of what constitutes the responsibility of business towards society has been addressed since the 1920s. Although a wide range of definitions for Corporate social responsibility (CSR) was proposed the concept remains disputed until today. The definition provided by Carroll (1999) received a lot of attention. "The social responsibility of business encompasses the economic, legal, ethical and discretionary expectations that a society has of organizations at a given point in time." Competing definitions tried to be more specific by emphasising the voluntary character of corporate social responsibility and linking it, thus, more strongly to ethical and philanthropic responsibilities than to economic and legal ones (Claasen \& Roloff, 2012). The European Union defines corporate social responsibility as "a concept whereby companies integrate social and environmental concerns in their business operations and in their interaction with their stakeholders on a voluntary basis". Dahlsrud (2008) developed five dimensions of CSR through a content analysis of existing CSR definitions and commented that "altogether, these five dimensions (1) stakeholder dimension, (2) social dimension, (3) economic dimension, (4) voluntariness dimension, and (5) environmental dimension are used consistently in the definitions. Although they apply different phrases, the definitions are predominantly congruent, making the lack of one universally accepted definition less problematic than it might seem at first glance (p. 7). The understanding of corporate responsibility being an essential part of management rather than a voluntary addition reflects the underlying assumption that companies need to actively ensure their legitimacy to be effective (Claasen \& Roloff, 2012). This assumption is more typical for an implicit understanding of CSR that is more commonly found in Europe (Matten \& Moon, 2008). Some recent theoretical 
conceptions of CSR (Basu \& Palazzo, 2008; Claasen \& Roloff, 2012) have expressed the idea that social responsible behaviour is instrumental to a company's legitimacy. Suchman (1995) also made a link between a company's active CSR management and legitimacy.

\section{Legitimacy}

Legitimacy focuses on whether the value system of an organisation is consistent with the value system of society, and whether the objective of organisations is to meet social expectations (Suchman, 1995). Legitimacy is a condition or a status which exists when an entity's value system is congruent with the value system of the larger social system of which the entity is a part (Lindblom 1994 p. 2). Legitimacy is a generalised perception or assumption that the actions of an entity are desirable, proper or appropriate within a socially constructed system of norms, values, beliefs and definitions (Suchman, 1995, p. 574). The literature on organisational legitimacy tends to identify three alternative forms of obtaining and sustaining legitimacy, but the categorisation differs from author to author (Bitektine 2011). Dowling and Pfeffer (1975) define social legitimacy as the degree to which an organisation conforms to the prevailing social norms and values. They describe three ways of becoming a legitimate organisation:

First, the organisation can adapt its output, goals, and methods of operation to conform to prevailing definitions of legitimacy. Second, the organisation can attempt, through communication, to alter the definition of social legitimacy so that it conforms to the organisation's present practices, output, and values. Finally, the organisation can attempt, again through communication, to become identified with symbols, values, or institutions which have a strong base of social legitimacy. (Dowling \& Pfeffer 1975, p. 127)

Suchman (1995) articulated three types of legitimacy, being pragmatic, moral and cognitive, which co-exist and strengthen one another. Types of legitimacy are briefly discussed below.

Pragmatic legitimacy derived from people's perception that organisation is beneficial for themselves. It is thus a form of "exchange legitimacy" (Suchman 1995, p. 578) that serves the needs of self-interested individuals. By addressing stakeholder expectations companies can obtain pragmatic legitimacy. Stakeholder management literature has been widely acknowledged this fact. Some authors (Savage et al. 1991) suggest prioritising powerful vocal stakeholders but others (Freeman, Harrison, Wicks, Parmar \& de Colle, 2010) warn managers not to overlook the importance of more vulnerable stakeholder groups for a company's legitimacy in the longer term.

Cognitive legitimacy is the "mere acceptance of the organisation as necessary or inevitable based on some taken-for-granted cultural account" (Suchman 1995, p. 582). For example, companies in the food industry are perceived as more legitimate than companies in the tobacco industry because of the different nature of their products. Cognitive legitimacy is not investigative by nature. The third way described by Dowling and Pfeffer (1975) (i.e. through communicating a link between the firm and legitimate symbols, values and organisations) can influence cognitive legitimacy. This could be attained through a marketing approach that creates this cognitive link. Cognitive legitimacy emerges, when the society regards an organisation and its output, procedures, structures and leader behaviour as inevitable and necessary. This acceptance is based on mostly public assumptions (Palazzo \& Scherer, 2006, p. 72). It is difficult for the organisation to directly and strategically influence and manipulate perceptions as cognitive legitimacy operates mainly at the subconscious level (Suchman, 1995). 
Moral legitimacy is described as resulting from "a positive normative evaluation of the organisation and its activities" (Suchman 1995, p. 579). According to Suchman, a morally legitimate company is judged by its accomplishments, its work in accordance with socially accepted procedures, and its capacity to perform well and by having a charismatic leader. Palazzo and Scherer (2006) refine Suchman's concept by arguing that moral legitimacy results from a conscious moral judgment on "the organisation's output, procedures, structures and leaders" (p. 73). They propose that moral legitimacy is socially created in a reflection of reasons that are used and considered to justify a company's actions, practices, structures and results. This reflection can either have the characteristics of a discourse in which the better argument prevails and a consensus is reached resulting in "philosophical legitimacy" or it has a political nature and establishes "democratic legitimacy" (Scherer \& Palazzo 2007, p.1113). Koppell (2008, p. 182) refers to moral legitimacy as the "true meaning of the word legitimacy," because cognitive and pragmatic legitimacy imply only that an authority is acknowledged and surrendered to. It is not a decisive factor for cognitive and pragmatic legitimacy whether this authority deserves its status or imposes it. Organisational legitimacy is not a universal concept. Whether an organisation and its actions are perceived as legitimate is socially created, therefore subject to change depending on the social environment in which the organisation is based in. This study discussed managerial attitudes with regard to cognitive, pragmatic and moral legitimacy as done by Claasen and Roloff (2012).

\section{Relevant CSER Studies}

Managerial attitudes towards CSER in emerging economies could be somewhat different to that in the developed economies because of the socio-economic, (Xiao et al., 2005) and technological development (Williams \& Pei, 1999) differences between these groups of countries. Brief descriptions of CSER studies are provided in tables 1.

Table 1 Summary of Studies on Attitudes towards CSER

\begin{tabular}{|c|l|l|l|}
\hline & $\begin{array}{l}\text { Research } \\
\text { methods }\end{array}$ & $\begin{array}{l}\text { Brief } \\
\text { Description }\end{array}$ & CSER Studies \\
\hline $\begin{array}{l}\text { Studies on } \\
\text { developed } \\
\text { economies }\end{array}$ & $\begin{array}{l}\text { Questionn } \\
\text {-aires and } \\
\text { interviews }\end{array}$ & $\begin{array}{l}\text { Predominantly } \\
\text { qualitative studies } \\
\text { which directly } \\
\text { explore managerial } \\
\text { attitude towards } \\
\text { SER }\end{array}$ & $\begin{array}{l}\text { Arvidsson, 2010; Cummings, 2008; } \\
\text { Fukukawa, et al., 2007; Michael, Echols } \\
\text { and Bukowski, 2010; Petts, Herd \& }\end{array}$ \\
$\begin{array}{l}\text { O'Heocha, 1998; Shafer, 2006; Stanaland, } \\
\text { Lwin and Murphy, 2011; Yakovleva and } \\
\text { Vazquez-Brust, 2012. }\end{array}$ \\
$\begin{array}{l}\text { Studies on } \\
\text { elopi } \\
\text { economies }\end{array}$ & $\begin{array}{l}\text { Questionn } \\
\text {-aires and }\end{array}$ & $\begin{array}{l}\text { Predominantly } \\
\text { qualitative studies } \\
\text { which directly } \\
\text { explore managerial } \\
\text { attitude towards } \\
\text { SER }\end{array}$ & $\begin{array}{l}\text { Balasubramanian et al., (2005); Belal and } \\
\text { Owen, (2007); Islam and Dellaportas } \\
\text { (2011); Islam and Deegan, (2008); Jaggi } \\
\text { and Zhao, (1996); Kim and Park (2011) } \\
\text { Kuasirikun, (2005); Lawrence, and Roper, } \\
\text { (2004); Liangrong and Song, (2008). } \\
\text { Rahaman, 2000; Rahaman, Teoh and } \\
\text { Thong, (1984); Tian, Wang and Yang, } \\
\text { (2011). }\end{array}$ \\
\hline
\end{tabular}


In studies based in emerging economies, management attitudes and interpretations of SER have been explored by Jaggi and Zhao, (1996); Kuasirikun (2005); Belal and Owen, (2007), Islam and Deegan, 2008; Islam and Dellaportas, 2011; and Tian et al., 2011. Investigating the attitudes of managers and management accountants in Hong Kong, Jaggi and Zhao (1996) commented that although managers were concerned about the protection of the environment in Hong Kong, but they did not show much enthusiasm to convert their attitudes into action. A similar attitude was found by Kuasirikun (2005) who evaluated attitude to social and environmental accounting among Thai managers and management accountants. The author argued that changing attitude will have to involve a change in the nature of the Thai accounting profession.

Liangrong and Song (2008) investigated how Chinese senior executives and middle level managers perceive and interpret CSER, to what extent firms' characteristics influence managers' attitudes towards CSER and whether their values in favour of CSER are positively correlated to firms' economic performance. They found an overall favourable view, but the true nature of their attitude was linked to entrepreneurs' gaining economic benefits. They also found that managers of firms smaller in size, state- owned, and located in poorer regions are more likely to strongly support CSER. Tian et al. (2011) examined the attitude of consumers towards CSER in China. The authors found that product categories influence the consumer responses to CSER not the responsibility. The authors concluded that consumers with middle level of age and income showed positive attitude towards CSER.

Belal and Owen (2007), Islam and Deegan (2008) and Islam and Dellaportas (2011) have explored the attitudes of managers of Bangladeshi companies. Using 23 semi-structured interviews, managerial perceptions of Bangladeshi organisations had been studied by Belal and Owen (2007). The results propose that a desire to manage powerful stakeholder groups was the main drive behind Bangladeshi CSER. They commented that "outside forces" and pressure from international buyers are eventual motivating force behind rising CSER practices in Bangladesh. Using legitimacy theory as a framework, the drive for Bangladeshi CSER had been re-examined by Islam and Deegan (2008). The results are similar to that of Belal and Owen (2007). Belal and Owen (2007) also claim that social policy and reporting in the garment industry is compelled by such pressure. Rahaman (2000) explored senior management attitudes towards CSER in Ghana, and found that the principal determinants of their attitudes were pressures from international lending agencies (such as the World Bank and the IMF), management philosophy, government regulation and the desire to achieve listing on international stock markets. Rahman et al. (2004) explored this issue further in a later study and found that the main driving force behind CSER in the Volta River Authority was external pressure from international lending institutions such as the World Bank.

In summary, few studies have investigated managerial attitudes towards CSER. The minute amount of literature looking at emerging economies suggests that corporate attitudes could be somewhat different from that found in developed economies. Belal and Momin (2009) argued that the difference could be because of the differences in the level of socio-economic and technological development between these two groups of countries. Various authors (Belal \& Owen, 2007; Islam \& Deegan, 2008; Rahman et al. 2004) argued that consumer pressure or pressure from non-government organisations or civil society groups are the driving force for CSER in organisations in developed economies. In contrast, the driving force of CSER in organisations in emerging economies which depend on foreign loans and aid, could be external pressure from international lending institutions (Rahman et al. 2004), pressure from particular stakeholders (such as international buyers) to upgrade their social performance, which shaped 
their social policy (Belal \& Owen, 2007), pressure from outside forces via parent company's instructions and pressure from international buyers (Islam \& Deegan, 2008). Table 2 summaries the key variables and related study on emerging economy.

Table 2 Summary of the Key Variables and Related Study on Emerging Economy

\begin{tabular}{|l|l|}
\hline Key Variable & Study \\
\hline Differences in the level of socio-economic & Xiao et al., 2005. \\
\hline Technological development & Williams and Pei, 1999. \\
\hline External pressure from international lending institutions & Rahman et al. 2004. \\
\hline Pressure from particular stakeholders & Belal and Owen, 2007. \\
\hline $\begin{array}{l}\text { Pressure from outside forces via parent company's } \\
\text { instructions and pressure from international buyers }\end{array}$ & Islam and Deegan, 2008 \\
\hline Age and level of income & Tian et al. 2011 \\
\hline
\end{tabular}

Managerial attitudes towards CSER in India have not been researched. Scant research has attempted to describe CSER for certain emerging economies in Asia such as Bangladesh, China and Thailand. Therefore, using data from Indian companies, this study aims to examine Indian managerial attitudes towards CSER.

\section{$4 \quad$ Research Method to Assess Managerial Attitudes}

\subsection{Survey Instrument Development}

Similar to Bhattacharyya and Cummings (2013) and Fukukawa et al. (2007) the survey research method is used in this study. A paper-based questionnaire was used for the survey. The questionnaire drew on different issues arising from CSER literature to ascertain managerial attitudes towards these issues and how these issues influence attitudes toward the social and environmental responsibility of Indian managers. Accordingly, the questionnaire was structured and divided into three sections: managerial attitudes toward social responsibility; managerial attitudes toward environmental responsibility; and demographic questions. Interval response scales of 1- 5 (Likert Scale e.g., 1 strongly disagree to 5 strongly agree) were used.

The social responsibility section was developed using 18 items (see table 4). Five items (B1, B2, B6, B7 and B9) measured respondent's attitude towards social rules, three items (B4, B13 and B17) measured respondent's attitude towards employees and their rights, while three items (B8, $\mathrm{B} 10$ and B11) measured respondent's attitude towards corporate social responsibility and reporting. Another four items (B3, B5, B15 and B18) measured respondent's attitude towards their community and towards corruption prevention. The remainder measured respondent's attitude towards customer health and safety and resource constraints. The environmental responsibility section (see table 5) consisted of 16 questions. Five items (C9, C10, C11, C12 and C13) measured respondent's attitude towards different aspects of environmental reporting; two (C3 and C16) measured their attitude towards trade sanctions and environmental taxes. Respondent's attitude towards increased government regulations, independent verification, compliances and enforcement of environmental regulations were measured by four items $(\mathrm{C} 4$, $\mathrm{C} 8, \mathrm{C} 14$, and $\mathrm{C} 15)$, whilst another two items (C1 and $\mathrm{C} 2$ ) measured attitudes towards local culture and values. The other items measured attitudes towards an environmental management system, recording of greenhouse gas emissions and policy decisions. The demographic section of the questionnaire (see table 3) included questions relating to age, gender, education level and managerial position. 


\subsection{Data Collection}

The data was collected through a professional data collection agency, Market Xcel Data Matrix Pvt Ltd, which had the necessary expertise and manpower to facilitate a higher response rate. A sample size of 350 organisations from three industries (Chemical, Industrial Engineering and Pharmaceutical/Biotech) was randomly selected. These industries were selected based on the social perceptions that organisations operating in these Chemical, Industrial Engineering and Pharmaceutical/Biotech industries are more likely to be considered socially and environmentally sensitive (Elkington, 1994). Many prior studies have compared between industries, this study examined the effect within one industry group considered socially and environmentally sensitive thus contributes to the theory of legitimacy. Industry classification and companies were selected randomly from the list of companies provided by the electronic database, DataStream Advance 4. An industry wide list of selected companies along with a questionnaire was supplied to Market Xcel Data Matrix Pvt Ltd, for collating the information. This data collection company maintained data originality and independence by following the International Code on Market and Social Research (ICC/ESOMAR) guidelines, (www.esomar.org) and maintained international delivery standards. To maintain data originality and reduce the risk of a low response rate, the author was personally present in India (at the beginning of the collection process) and oversaw (gave instructions from time to time) data collection to avoid possible data duplication and fraud, and to make sure that the data collected was original, legitimate and reliable. The firm randomly selected participants from their database who were middle / top level corporate / branch managers of companies. The firm delivered questionnaires to the selected participants, who had the option to complete it in their own time. The firm personally collected the completed questionnaires after a period of approximately one week from the participants. Due to the different operational environment in India it was prudent to have a professional firm deliver and collect the questionnaires, as mailed questionnaires would most likely remain unanswered without a personal approach. A total of 170 questionnaires were finally received with responses.

\subsection{Analysis}

The aim of this study is to explore the Indian managerial attitude towards social and environmental responsibility. Hence, a three-step data analysis procedure was undertaken in this study. In the first step, responses to scale items by the respondents were analysed. In the next step, an exploratory principal components analysis (PCA) with varimax rotation and Kaiser normalisation was undertaken to identify the number of factors that underlie the variables of social and environmental responsibility. In the final stage a confirmatory factor analysis (CFA) was also undertaken to confirm the social and environmental factors in the study. Factor analysis is a data reduction technique that can be used for reducing a large number of variables to a smaller set of underlying factors that summarize the essential information contained in the variables (Coakes, Steed \& Ong, 2010). PCA helped the researcher in evaluating the new scales developed for the study, by identifying the underlying structure (dimensions) of the key constructs. Next, the CFA enabled confirmation of the discriminant validity of the key constructs. Finally, a full structural model tested the relationships developed in the conceptual model. 


\section{Findings}

\subsection{Descriptive Analysis}

Respondents' positions ranged from vice president to assistant manager, with $11 \%$ holding a director's position and $62 \%$ managerial positions. The majority $(67 \%)$ of respondents was aged between 25 and 44 years and most (90\%) were male. All respondents identified themselves as Indians with Indian cultural background, with many having a master's degree (45\%). The preliminary analysis indicated that overall, the data had moderate levels of skewness, (between 1.395 and -0.254) indicating normal distribution. The findings enabled the researcher to explore the responses to each question in the survey and understand the symmetry of the data.

Table 3 Descriptive Statistics of Respondents

\begin{tabular}{|c|c|c|c|}
\hline Characteristic & Attributes & $N=170$ & $\%$ \\
\hline \multirow[t]{2}{*}{ Gender } & Male & 153 & 90 \\
\hline & Female & 17 & 10 \\
\hline \multirow[t]{5}{*}{ Age } & Under 25 & 5 & 2.9 \\
\hline & 25-34 years & 46 & 27.1 \\
\hline & $35-44$ years & 64 & 37.6 \\
\hline & $45-54$ years & 37 & 21.8 \\
\hline & $55+$ years & 18 & 10.6 \\
\hline \multirow[t]{3}{*}{ Country of birth } & Australia & Nil & \\
\hline & India & 170 & 100 \\
\hline & Others & Nil & \\
\hline \multirow[t]{3}{*}{$\begin{array}{l}\text { Resided in the country of } \\
\text { residence }\end{array}$} & $>10$ years & 4 & 2.4 \\
\hline & 10 to 20 years & 20 & 11.8 \\
\hline & 20 years + & 146 & 85.9 \\
\hline \multirow[t]{4}{*}{ Education } & $\begin{array}{l}\text { Non-university } \\
\text { Post secondary }\end{array}$ & 14 & 8.2 \\
\hline & Bachelors & 77 & 45.3 \\
\hline & Masters & 77 & 45.3 \\
\hline & others & 2 & 1.2 \\
\hline \multirow[t]{5}{*}{ Occupation } & Director & 19 & 11.2 \\
\hline & Manager & 100 & 58.8 \\
\hline & $\mathrm{C} \mathrm{EO}$ & 4 & 2.4 \\
\hline & $\begin{array}{l}\text { Chief } \\
\text { Accountant }\end{array}$ & 2 & 1.2 \\
\hline & Others & 45 & 26.5 \\
\hline
\end{tabular}

It is indicated in table 4 that the mean responses to most of the social responsibility items ranged from 3.59 to 4.30 . This suggests that average respondents in the study had high support for the most of the social responsibility related items of the questionnaire. The low standard deviation (narrow spread) of scaled items reflects a greater consensus of attitude amongst Indian managers (Shafer, 2006). Respondents supported strongly about a range of issues on social responsibility, ranging from corruption prevention policies, customer health and safety, sustainability report, and employee's rights and benefits. This finding indicates that respondents are concerned about a range of issues surrounding social responsibility. Alternatively it can be suggested that three issues of health and safety (mean score 4.33), corruption prevention, (mean 
score 4.33) and employee benefits, (mean score 4.26) have been the key social issues perceived by the participated Indian managers. On the down side, the Indian respondents more or less provided the least support to the organisations' community involvement, educating employees about social rules, the practice of higher ethical standards by Indian managers and the resource constraints to influence the discharge of social responsibility.

The mean response to the environmental responsibility items ranged from 3.59 to 4.20 , suggesting that the respondents were in good favour of the questions. The respondents mostly favoured specific issues concerning environmental responsibility such as, the acquisition of international standards for environmental management system, keeping records of the amount of greenhouse gas emissions, consultation with various stakeholder groups while making environmental policy decisions, standalone environmental reporting, and poor compliance with environmental regulations. At the same time they moderately favoured the rest of the items on environmental responsibility. This finding also indicates that respondents are concerned about environmental responsibility, however they categorised few issues to be more important over other environmental factors.

\section{Table 4 Mean Scores of Social Responsibility Items}

\begin{tabular}{|c|c|c|}
\hline & Social responsibility item description & Mean (Sd) \\
\hline B17 & $\begin{array}{l}\text { An organisation should make its policies on corruption prevention publicly } \\
\text { available. }\end{array}$ & $4.30(0.72)$ \\
\hline B16 & $\begin{array}{l}\text { An organisation should make its policies on customer health and safety } \\
\text { publicly available. }\end{array}$ & $4.21(0.74)$ \\
\hline B10 & A sustainability report will improve the image of an organisation. & $4.16(0.64)$ \\
\hline B15 & $\begin{array}{l}\text { The full range of organisational employee benefits should be made available to } \\
\text { all employees. }\end{array}$ & $4.15(0.75)$ \\
\hline B14 & Corporate social responsibility (CSR) reporting should be mandatory. & $4.11(0.78)$ \\
\hline $\mathrm{B} 13$ & $\begin{array}{l}\text { Informing employees about their rights is the responsibility of top } \\
\text { management. }\end{array}$ & $4.09(0.83)$ \\
\hline $\mathrm{B} 2$ & $\begin{array}{l}\text { The cultural values of a country directly influence the development of an } \\
\text { organisation's social reporting system. }\end{array}$ & $4.04(0.75)$ \\
\hline B8 & Social codes of conduct encourage an organisation to be more accountable. & $4.03(0.75)$ \\
\hline B6 & Educating employees about social rules is the organisation's responsibility. & $4.01(0.90)$ \\
\hline B11 & A sustainability report will improve the competitiveness of an organisation. & $3.98(0.79)$ \\
\hline B1 & $\begin{array}{l}\text { The social rules of a country influence individual attitudes towards } \\
\text { accountability. }\end{array}$ & $3.98(0.71)$ \\
\hline $\mathrm{B} 18$ & $\begin{array}{l}\text { An organisation should make its policies on the extent of local area } \\
\text { employment publicly available. }\end{array}$ & $3.92(0.79)$ \\
\hline B9 & Organisations must discharge their social obligations to survive. & $3.88(0.85)$ \\
\hline B3 & $\begin{array}{l}\text { The needs of society overall are just as important, if not more important in } \\
\text { managerial decision making, as the specific needs of the shareholder. }\end{array}$ & $3.83(0.843)$ \\
\hline$\overline{\mathrm{B} 7}$ & $\begin{array}{l}\text { Multinational organisations apply a higher standard of social responsibility in } \\
\text { their home (domiciled) country. }\end{array}$ & $3.82(0.86)$ \\
\hline B5 & $\begin{array}{l}\text { The primary area of social concern for organisations is community } \\
\text { involvement. }\end{array}$ & $3.79(0.93)$ \\
\hline B4 & $\begin{array}{l}\text { Managers in this country are more likely to practice higher ethical standards } \\
\text { than managers overseas. }\end{array}$ & $3.69(0.90)$ \\
\hline B12 & $\begin{array}{l}\text { Resource constraints are the main obstacle for organisations wishing to } \\
\text { discharge their social responsibility. }\end{array}$ & $3.59(0.96)$ \\
\hline
\end{tabular}


Table 5 Mean Scores of Environmental Responsibility Items

\begin{tabular}{|c|c|c|}
\hline & Environmental responsibility item description & Mean (Sd) \\
\hline $\mathrm{C} 4$ & $\begin{array}{l}\text { A register to record the amount of greenhouse gas emissions } \\
\text { should be maintained by corporations in the manufacturing industry. }\end{array}$ & $4.20(0.61)$ \\
\hline $\mathrm{C} 3$ & $\begin{array}{l}\text { Corporations in the manufacturing industry should acquire } \\
\text { ISO14001 - the international standard for environmental } \\
\text { management systems. }\end{array}$ & $4.15(0.76)$ \\
\hline C9 & Individual environmental behaviour is influenced by local culture. & $4.09(0.68)$ \\
\hline $\mathrm{C} 16$ & $\begin{array}{l}\text { Weak enforcement by authorities causes poor organisational compliance } \\
\text { with environmental regulations. }\end{array}$ & $4.08(0.65)$ \\
\hline $\mathrm{C} 5$ & $\begin{array}{l}\text { Managers should consult with various stakeholder groups when making } \\
\text { environmental policy decisions. }\end{array}$ & $4.06(0.79)$ \\
\hline $\mathrm{C} 7$ & $\begin{array}{l}\text { A stand- alone environmental report (separate from an annual report) } \\
\text { should be published by organisations operating in the manufacturing } \\
\text { industry. }\end{array}$ & $4.01(0.76)$ \\
\hline C6 & $\begin{array}{l}\text { Local organisations should be subject to the same degree of } \\
\text { environmental scrutiny as organisations from foreign countries (i.e. } \\
\text { multinationals). }\end{array}$ & $3.99(0.81)$ \\
\hline $\mathrm{C} 2$ & $\begin{array}{l}\text { Trade sanctions should be imposed on countries not complying with } \\
\text { international environmental agreements. }\end{array}$ & $3.97(0.82)$ \\
\hline $\mathrm{C} 15$ & $\begin{array}{l}\text { An increase in government regulations/oversight will encourage a more } \\
\text { balanced approach to environmental reporting. }\end{array}$ & $3.96(0.74)$ \\
\hline $\mathrm{C} 13$ & $\begin{array}{l}\text { Reporting on its environmental activities can add value to an } \\
\text { organisation and help it reduce costs in the long term }(>3 \mathrm{yrs}) \text {. }\end{array}$ & $3.94(0.71)$ \\
\hline $\mathrm{C} 8$ & $\begin{array}{l}\text { An organisation's environmental performance should be subject to } \\
\text { independent verification by a government authority. }\end{array}$ & $3.91(0.92)$ \\
\hline $\mathrm{C} 14$ & $\begin{array}{l}\text { Environmental taxes can be an important way of achieving reductions in } \\
\text { greenhouse gases. }\end{array}$ & $3.79(0.96)$ \\
\hline $\mathrm{C} 10$ & $\begin{array}{l}\text { Most organisations do not report environmental information because } \\
\text { they believe their operations do not have significant environmental } \\
\text { impact. }\end{array}$ & $3.77(0.84)$ \\
\hline $\mathrm{C} 12$ & $\begin{array}{l}\text { Reporting on its environmental activities can add value to an } \\
\text { organisation and help it reduce costs in the short term }(<3 \mathrm{yrs}) \text {. }\end{array}$ & $3.72(0.84)$ \\
\hline $\mathrm{C} 1$ & $\begin{array}{l}\text { The degree of pressure from stakeholders determines the level of } \\
\text { environmental reporting by an organisation. }\end{array}$ & $3.65(0.83)$ \\
\hline C11 & $\begin{array}{l}\text { Most organisations do not report environmental information because } \\
\text { they do not have the resources to do so. }\end{array}$ & $3.59(0.94)$ \\
\hline
\end{tabular}

\subsection{Principal Components Analysis (PCA)}

A PCA (using SPSS) with varimax rotation and Kaiser normalisation was used to explore the underlying dimension or factors for social and environmental responsibility of respondents. This provided a better understanding of which factors constitute both social and environmental responsibility for the respondents. Cronbach's Alpha test was undertaken to test the reliability of the items. The values of the Cronbach's Alpha ware in the range of .80 to .60 , which is considered acceptable for exploratory measures (Nunnally, 1967). However, before conducting the analysis several diagnostic tests were performed to ensure that valid conclusions are drawn based on the factor analysis. Barlett's test of sphericity and the Kaiser-Meyer-Olkin (KMO) measure of sampling adequacy was also performed to determine the factorability of the matrix. 
To check the normality of the data, skewness and kurtosis of the variables were examined. The skewness and kurtosis of all of the observations were within the range of $2 \times$ Standard Error. Linearity was checked by scatterplots of pairs of variables. The Bartlett's test ensured that the correlations were significant at the .001 level and the Kaiser-Meyer-Olkin (KMO) measure of sampling adequacy (MSA) value falls in the acceptable range (above 0.50 ) with a value of 0.729 indicating that the variables meets the fundamental requirements for factor analysis.

\subsubsection{PCA of social responsibility}

The analysis revealed five interpretable factors that explain $58.6 \%$ of the total variance. Table 6 present the results. Indian managers considered factors internal to the organisation such as social rules and responsibilities (factor 1), availability of information (factor 2), needs and responsibilities of organisation (factor 3), influences on social accountability (factor 4), and sources within organisations (factor 5) to measure social responsibility.

Factor one, which is referred to herein as 'social rules and responsibilities', based on its items commonality represent the social obligation, social codes and responsibility of the organisation. This factor consists of three items, B14, B9 and B8 that load in the range of 0.61 to 0.65 . Similarly, factor two has three items B16, B15, and B18, that loaded in the range of 0.52 to 0.82 . However, the respondents considered that these two items along with item B16 to be important items that represent the organisations' role in making policies related to employment, employee benefit, and customer health and safety available to people. This is evident by the mean score of the three items ranging from 3.92 to 4.21 and high loading of the three items together on one factor proving its discriminant validity, (Nunnally \& Bernstein, 1994). Hence, factor two is labelled as 'public availability of organisational policies'.

The third factor consisted of three items, B3, B6, and B13. The analysis revealed items B6, (educating employees about social rules) B13, (informing employees about their rights) and B3, (societal needs are important) loaded on one factor in the range of 0.52 to 0.64 . Hence, we named these three items as, 'needs and responsibilities of the organisation', based on their item commonalities that represented the factor. Factor four consisted of two items B1, (social rules of a country influence individual attitudes toward accountability) and B2, (cultural values of a country directly influence the development of an organisation's social reporting system), that loaded in the range of 0.75 to 0.85 . These two items are named as, 'influence on social accountability'. This decision was taken to remain consistent with other dimensions of social accountability to represent the factors internal to the organisation, as mentioned above. The five factors of social accountability displayed good reliability score in the range of 0.8 to 6.5 (Nunnally and Bernstein, 1994). Thus, all factor loadings and the factor reliabilities for the SEA items were relatively high, suggesting that these items measure five distinct constructs. Based on the factor loadings few factors such as factor 4 'Influences on social accountability' (average load .80), factor 5 'Organisational sources to improve social accountability' (averageload.73) and factor 2 'Public availability of organisational policies' (average load .70) were more important than other factors. It also indicates that important variables according to factor loadings are B1 (.85), B16 (.82), B2, B15 (.75) and B12 (.74). 
Table 6 Factor Analysis of Social Responsibility

\begin{tabular}{|c|c|c|c|c|c|}
\hline & $\begin{array}{c}\text { Factor } \\
1\end{array}$ & $\begin{array}{c}\text { Factor } \\
2 \\
\end{array}$ & $\begin{array}{c}\text { Factor } \\
3 \\
\end{array}$ & $\begin{array}{c}\text { Factor } \\
4 \\
\end{array}$ & $\begin{array}{c}\text { Factor } \\
5\end{array}$ \\
\hline \multicolumn{6}{|l|}{ Social rules and responsibilities } \\
\hline $\begin{array}{l}\text { B14: Corporate social responsibility } \\
\text { reporting should be mandatory. }\end{array}$ & .65 & & & & \\
\hline $\begin{array}{l}\text { B9: Organisations must discharge their } \\
\text { social obligations to survive. }\end{array}$ & .63 & & & & \\
\hline $\begin{array}{l}\text { B8: Social codes of conduct encourage an } \\
\text { organisation to be more accountable. }\end{array}$ & .61 & & & & \\
\hline \multicolumn{6}{|l|}{$\begin{array}{l}\text { Public availability of organisational } \\
\text { policies }\end{array}$} \\
\hline $\begin{array}{l}\text { B16: An organisation should make its } \\
\text { policies on customer health and safety } \\
\text { publicly available. }\end{array}$ & & .82 & & & \\
\hline $\begin{array}{l}\text { B15: The full range of organisational } \\
\text { employee benefits should be made available } \\
\text { to all employees. }\end{array}$ & & .75 & & & \\
\hline $\begin{array}{l}\text { B18: An organisation should make its } \\
\text { policies on the extent of local area } \\
\text { employment publicly available. }\end{array}$ & & .52 & & & \\
\hline \multicolumn{6}{|l|}{ Responsibilities of organisation } \\
\hline $\begin{array}{l}\text { B3: The needs of society overall are just as } \\
\text { important, if not more important in } \\
\text { managerial decision making, as the specific } \\
\text { needs of the shareholder. }\end{array}$ & & & .64 & & \\
\hline $\begin{array}{l}\text { B6: Educating employees about social rules } \\
\text { is the organisation's responsibility. }\end{array}$ & & & .56 & & \\
\hline $\begin{array}{l}\text { B13: Informing employees about their rights } \\
\text { is the responsibility of top management. }\end{array}$ & & & .52 & & \\
\hline \multicolumn{6}{|l|}{ Influences on social responsibility } \\
\hline $\begin{array}{l}\text { B1: The social rules of a country influence } \\
\text { individual attitudes toward responsibility. }\end{array}$ & & & & .85 & \\
\hline $\begin{array}{l}\text { B2: The cultural values of a country directly } \\
\text { influence the development of an } \\
\text { organisation's social reporting system. }\end{array}$ & & & & .75 & \\
\hline \multicolumn{6}{|l|}{$\begin{array}{l}\text { Organisational sources to improve social } \\
\text { responsibility }\end{array}$} \\
\hline $\begin{array}{l}\text { B12: Resource constraints are the main } \\
\text { obstacle for organisations wishing to } \\
\text { discharge their social responsibility. }\end{array}$ & & & & & .74 \\
\hline $\begin{array}{l}\text { B10: A sustainability report will improve the } \\
\text { image of an organisation. }\end{array}$ & & & & & .71 \\
\hline
\end{tabular}





\subsubsection{PCA of environmental responsibility}

The items under factors 'disclosure of environmental information' and 'international standards and management of environmental accountability' load highly on their respective factors indicating good discriminant validity (Diamantopoulos, 2005). The reliability scores for all the four factors were in the range of 0.70 to 0.60 , indicating acceptable reliability, (Nunnally \& Bernstein, 1994). The analysis of data in Table 7 also revealed a four factor structure that explains $54.89 \%$ of the total variance. These four factors are herein labelled as; (i) Recording and Reporting of Environmental Matters, (ii) Environmental Governance, (iii) Environmental Process and, (iv) Environmental Report. From the analysis and description of the items under each factor it appears that these four factors contribute to the understanding of the concept of environmental accountability. Factor one 'Recording and Reporting of Environmental Matters' consists of four items (C15, C12, C4 and C13), that loaded in the range of 0.64 to 0.71 . These items showed a high loading on one factor proving its discriminant validity. At the same time all the four items on this factor contribute to the understanding and importance of recording and reporting of environmental matters for environmental accountability. The second factor consisted of three items, $\mathrm{C} 14, \mathrm{C} 2$, and $\mathrm{C} 16$, that loaded in the range of 0.56 to 0.67 . These three items represent the ways in which environmental accountability can be governed by imposing environmental taxes to reduce greenhouse gas emission (item C14), imposing sanctions on countries not complying with environmental regulations (item $\mathrm{C} 2$ ), and enforcing organisational compliance with environmental regulations (C16). Hence, we labelled this factor as 'EnvironmentalGovernance'.

The third factor consists of four items, $(\mathrm{C} 8, \mathrm{C} 5, \mathrm{C} 1$ and $\mathrm{C} 6)$ that loaded in the range of 0.44 to 0.78 . However, collectively when these four items were loaded on a single factor they represented a single underlying dimension of 'environmental processes. Wherein, the verification (item C8) consultation (item C5), disclosure (item C1) and scrutiny (item C6) of environmental policy or performance represent the process through which organisations or government authority could achieve environmental accountability.

Finally, the fourth factor labelled as 'environmental report' consists of three items C7, C11, and $\mathrm{C} 10$ that loaded in the range of 0.67 to 0.74 . The Indian data considered these items along with item $\mathrm{C} 7$, to significantly load on one factor, proving its discriminate validity from other factors. Hence, we labelled this factor as environmental report, based on its item commonalities. According to factor loading, all the variables (except C6 and C16) are important (factor loadings .64 and above). Although four factors contribute to the understanding of the concept of environmental accountability factor 4 'Environmental report' (average loading .71) and factor 1 'Recording and reporting environmental matters (average loading .67) were more than other factors based on average factor loading. The result indicated that the most important variable is 'an organisations environmental performance should be subject to independent verification by a government authority' with .78 factor loading. 
Table 7 Factor Loadings of Environmental Responsibility

\begin{tabular}{|c|c|c|c|c|}
\hline Environmental responsibility & $\begin{array}{c}\text { Factor } \\
1\end{array}$ & $\begin{array}{c}\text { Factor } \\
2\end{array}$ & $\begin{array}{c}\text { Factor } \\
3\end{array}$ & $\begin{array}{c}\text { Factor } \\
4\end{array}$ \\
\hline \multicolumn{5}{|l|}{$\begin{array}{l}\text { Recording and reporting of environmental } \\
\text { matters }\end{array}$} \\
\hline \begin{tabular}{lccc} 
C15: An & increase & in & \multicolumn{2}{c}{ government } \\
regulations/oversight & will & encourage & a more \\
balanced approach to environmental reporting. & &
\end{tabular} & .71 & & & \\
\hline $\begin{array}{l}\text { C12: Reporting on its environmental activities can } \\
\text { add value to an organisation and help it reduce costs in } \\
\text { the short term }(<3 \text { yrs }) \text {. }\end{array}$ & .67 & & & \\
\hline $\begin{array}{l}\text { C4: A register to record the amount of greenhouse } \\
\text { gas emissions should be maintained by } \\
\text { corporations in the manufacturing industry. }\end{array}$ & .67 & & & \\
\hline $\begin{array}{l}\text { C13: Reporting on its environmental activities can } \\
\text { add value to an organisation and help it reduce costs in } \\
\text { the long term }(>3 \mathrm{yrs}) \text {. }\end{array}$ & .64 & & & \\
\hline \multicolumn{5}{|l|}{ Environmental governance } \\
\hline $\begin{array}{l}\text { C14: Environmental taxes can be an important } \\
\text { way of achieving reductions in greenhouse gases. }\end{array}$ & & .67 & & \\
\hline $\begin{array}{l}\text { C2: Trade sanctions should be imposed on } \\
\text { countries not complying } \\
\text { environmental agreements. }\end{array}$ & & .63 & & \\
\hline $\begin{array}{l}\text { C16: Weak enforcement by authorities causes } \\
\text { poor } \quad \text { organisational } \\
\text { environmental regulations. }\end{array}$ & & .56 & & \\
\hline \multicolumn{5}{|l|}{ Environmental process } \\
\hline $\begin{array}{l}\text { C8: An organisation's environmental performance } \\
\text { should be subject to independent verification by a } \\
\text { government authority. }\end{array}$ & & & .78 & \\
\hline $\begin{array}{l}\text { C5: Managers } \\
\text { stakeholder groups } \\
\text { decisions. }\end{array}$ & & & .70 & \\
\hline $\begin{array}{l}\mathrm{C} 1 \text { : The degree of pressure from stakeholders } \\
\text { determines the level of environmental reporting by an } \\
\text { organisation. }\end{array}$ & & & .64 & \\
\hline $\begin{array}{l}\text { C6: Local organisations should be subject to the } \\
\text { same degree of environmental scrutiny as organisations from } \\
\text { foreign countries (i.e. multinationals). }\end{array}$ & & & .44 & \\
\hline \multicolumn{5}{|l|}{ Environmental report } \\
\hline $\begin{array}{l}\text { C7: A stand-alone environmental report (separate } \\
\text { from an annual report) should be published by organisations } \\
\text { operating in the manufacturing industry. }\end{array}$ & & & & .74 \\
\hline $\begin{array}{l}\text { C11: Most organisations } \\
\text { environmental information because } \\
\text { resources do so. }\end{array}$ & & & & .73 \\
\hline $\begin{array}{l}\text { C10: Most organisations do not report } \\
\text { environmental information because they believe their } \\
\text { operations do not have significant environmental impact. }\end{array}$ & & & & .67 \\
\hline
\end{tabular}




\subsection{Confirmatory Factor Analysis}

A confirmatory factor analysis (CFA) procedure was undertaken to confirm the factors for social and environmental responsibility. Based on the CFA findings a higher order model of Indian managerial attitude towards social and environmental responsibility is specified in the study. The confirmatory factor analysis (CFA) procedure is conducted using AMOS software. As recommended by Bollen and Long (1993), multiple fit indices were used to judge how well the proposed models of environmental responsibility fits the data. The study examined a non-significant Chi-Square $(\chi 2)$, the goodness of fit index (GFI) and the adjusted goodness of fit index (AGFI), requiring values of $>0.85$ and $>0.80$, respectively, to denote good fit (Marsh et al., 1988). The GFI and AGFI have been criticized as providing insufficient evidence of model fit but have been commonly reported. The root mean square error of approximation (RMSEA) and standardized root mean square residual (RMR), an index that provides an estimate of the magnitude of the average absolute discrepancy between predicted and observed correlations for each model, were also included as measures of model fit. Here, values less than 0.05 represent good fit, values of $0.05-0.08$ represent moderate fit, and values of 0.08 to 0.10 represent adequate fit (Brown \& Cudeck, 1993). Finally, two relative fit indices - the Tucker-Lewis Index (TLI) and comparative fit index (CFI) - were used with values of $>0.90$ considered to be consistent with good model fit In addition to the use of multiple fit indices mentioned above, the environmental responsibility model was also assessed on its internal structure by examination of the parameter estimates and the reliability of construct measures (Bagozzi \& Youjae, 1988). The standardised regression weights (SRW) $>0.70$ (Churchill, 1979) and Squared multiple correlation (R2) which are the item reliabilities of value $>0.50$ (Jöreskog \& Sörbom, 1996) are acceptable score to assess the model fit. The standardised residual covariance (SRC) with values $>2.50$ indicate cross loading of the item and hence considered as candidates for deletion from the model (Jöreskog \& Sörbom, 1996).

The final three factor model of social responsibility provided a very good model fit to the data as indicated by $(\chi 2(24)=52.62, \rho=.001)$ and supporting fit indices ( $\mathrm{RMSEA}=.085$, $\mathrm{GFI}=.93, \mathrm{AGFI}=.88, \quad \mathrm{RMR}=.042, \mathrm{TLI}=.82, \mathrm{CFI}=.88$ ). The three latent constructs; Social_Rules, Public_Availability and Needs \& Responsibilities provided in Figure 1 showed a significant factor coefficients ranging from a low of .34 (item B18) to a high of .72 (item B15). 
Figure 1

Three Factor Model of Social Responsibility

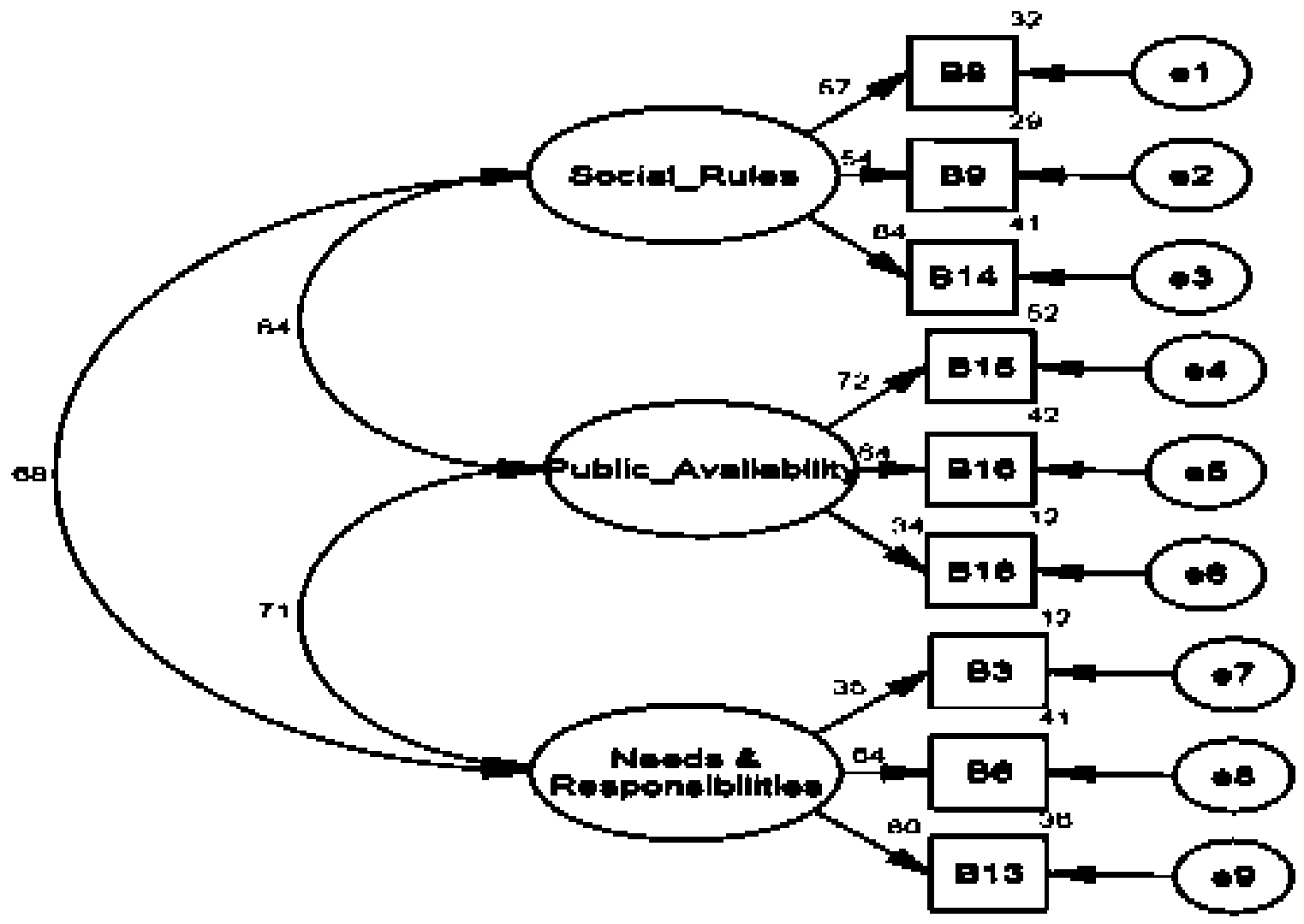

The four factor model of environmental responsibility showed good discriminant validity and item reliability in the range of 0.40 to .78 . The results showed a significant chi-square $\left(\chi^{2}\right.$ $(48)=98.34, \rho=.000$ ). However, the supporting fit indices (RMSEA=.07, GFI=.91, $\mathrm{AGFI}=.86, \mathrm{RMR}=.052$, $\mathrm{TLI}=.69, \mathrm{CFI}=.77$ ) showed a good model fit to the data. The four factor model of environmental responsibility is presented in in figure 2. 
FIGURE 2

Four Factor model of Environmental responsibility

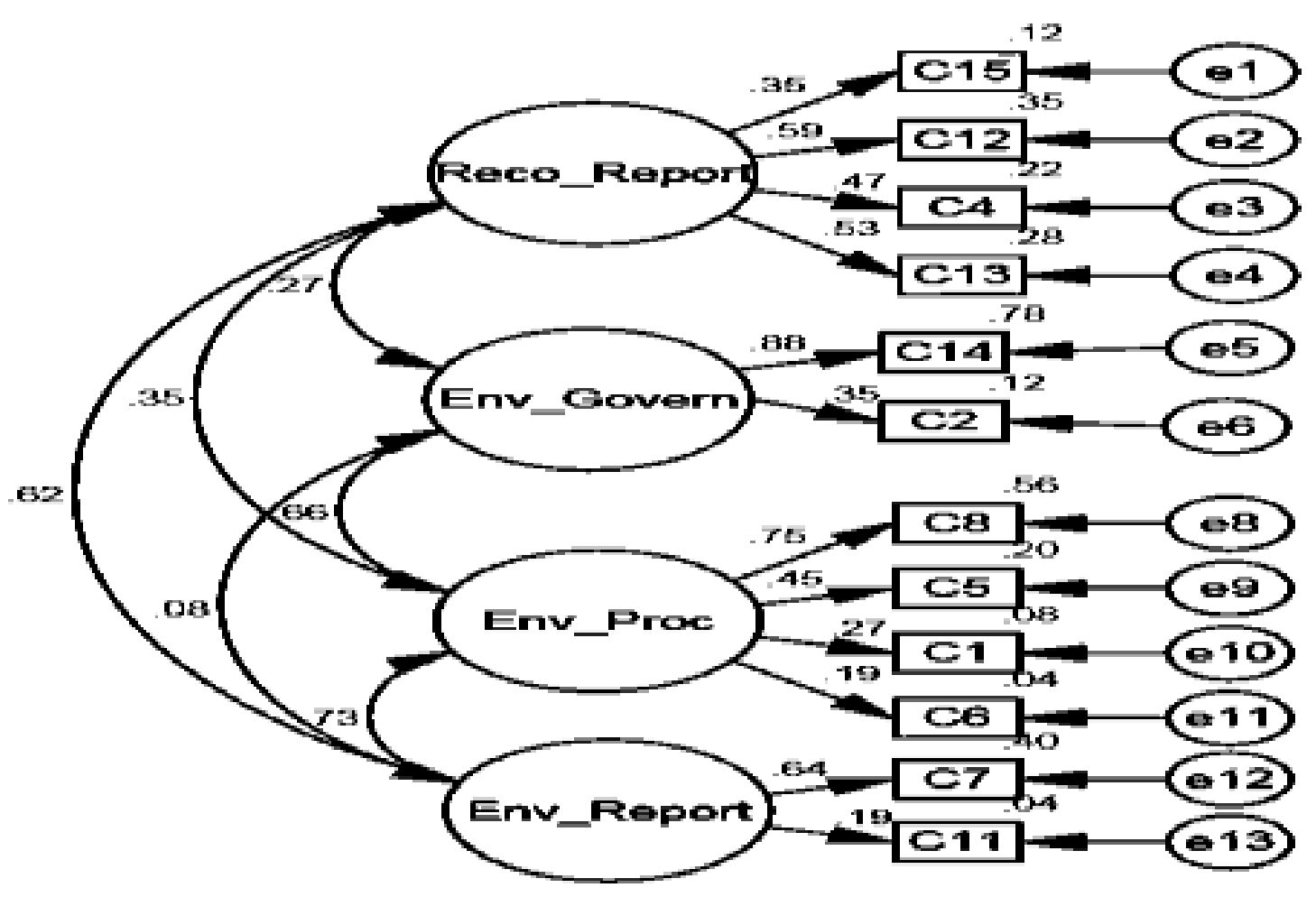

\subsubsection{Managerial attitude towards social and environmental responsibility}

Based on the CFA results a higher order model of Indian managerial attitude was specified with two latent first order factors of social and environmental responsibility. Composite scale were developed for the three factors of social responsibility; Needs \& Responsibilities, Public_Availability and Social_Rules and four factors of environmental responsibility; Reco_Report, Env_Govern, Env_Proc and Env_Report. Figure 3 shows the results of the final model. The chi-square results provided a good fit to the data $\left(\chi^{2}(13)=28.6, \rho=.007\right)$ along with fit indices (RMSEA=.084, GFI =.95, AGFI=.90, RMR=.022, TLI=.87, CFI=.92). The factor loadings from social responsibility to its three factors Social_Rules, Public_Avaliability, Needs_Responsibilities were in the acceptable range of 0.59 to 0.66 (Churchill 1979). The four factors of environmental responsibility; Reco_Report, Env_Govern, Env_Proc, Env_Report explain a relatively lower percent of variance on its factor as indicated by lower range of 0.45 to 0.63 . The standardised regression from Indian managerial attitude to social $(\beta=0.82$ at $\rho \leq 0.001)$ and environmental $(\beta=0.82$ at $\rho \leq 0.001)$ responsibility indicates that the Indian respondents consider social responsibility to explain a higher percent of variance $(90 \%)$ in managerial attitude than environmental responsibility at 
$82 \%$.

FIGURE 3

Model of Managerial Attitude towards Social and Environmental responsibility

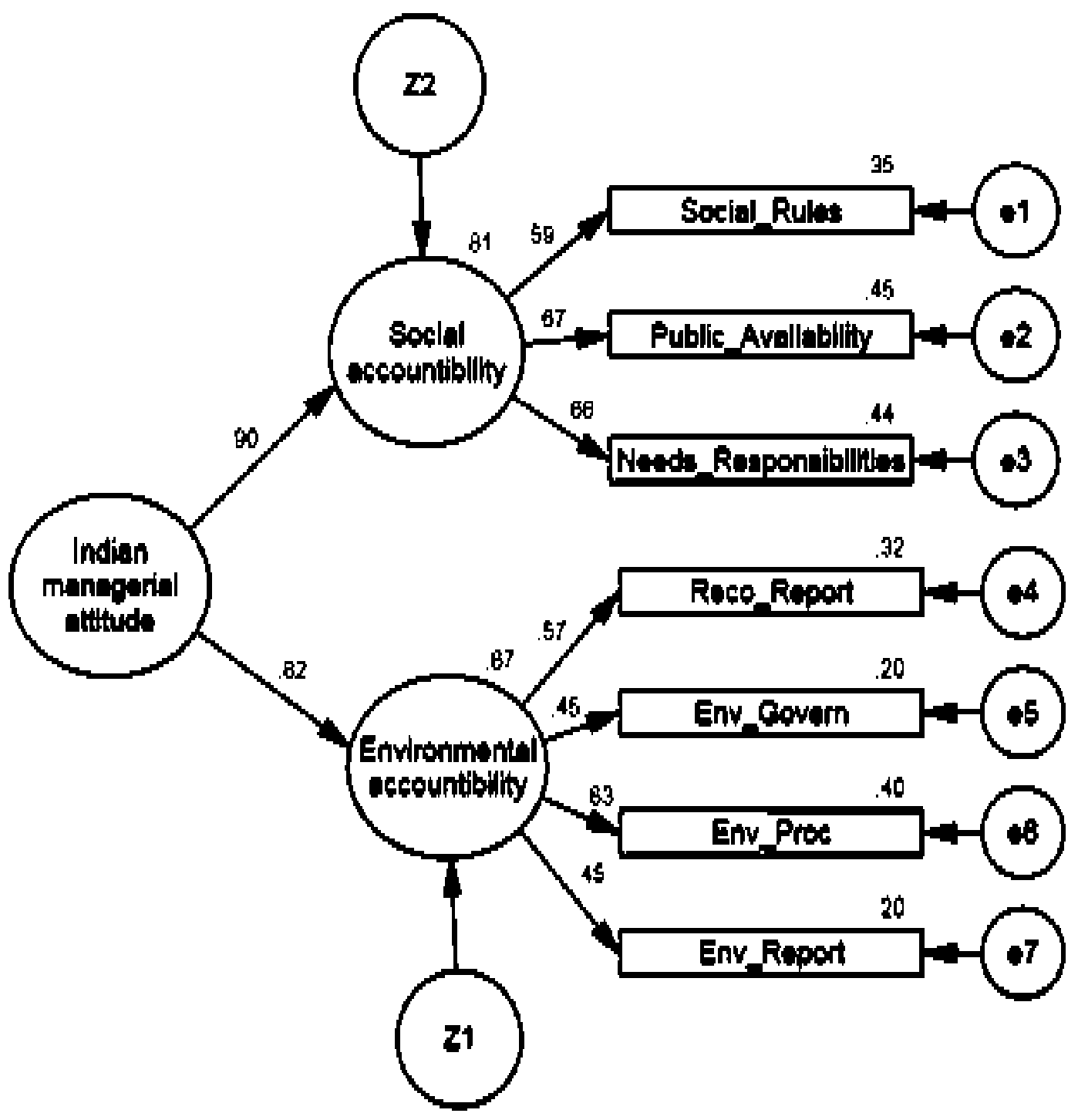

\section{Discussion and Conclusion}

This study attempts to obtain a better understanding of managerial attitudes toward CSER within developing Asian economies, but particularly Indian managerial attitudes. The results suggest that respondents to the study had strong support for most of the social responsibility related items of the questionnaire. Relatively lower standard deviation reflected greater consensus of attitude amongst respondents. The result indicates that Indian managers are concerned about a range of social issues and is evidenced by their strong support for a customer health and safety policy, organisational employee benefits, polices on corruption 
prevention, corporate social responsibility, sustainability reporting, educating employees about social rules, informing employees about their rights, employee benefits and organisation's social reporting. The result also indicates that social responsiveness in India has increased as Raman (2006) found that Indian organisations place emphasis only on service improvement and development of human resources. Respondents also exhibited strong environmental support, favouring specific issues concerning environmental responsibility such as international standards for an environmental management system, keeping records of greenhouse gas emissions, consultation with stakeholder groups when making environmental policy decisions and publication of stand-alone environmental reporting.

PCA on social responsibility revealed five factors for Indian respondents. Factor 4 (average load .80) and variable B1 ('social rules of a country influences individual attitudes towards responsibility', loading .85), was most important for Indian respondents. The concept of responsibility, which emerged in the developed capitalist countries where rule of law and other formal and informal institutions provide a solid foundation for market transactions, began to spread in India only recently. While companies in the developed country contexts are able to operate and resolve economic conflicts by accepted norms, acting responsibly in the context of India more rests with exercising managerial ethics. The responsibility conception with Indian characteristics may also be influenced by the cultural tradition. The abiding influence of cultural ethics probably justifies high loading (average .80) for ethics \& social rules by many Indian managers. The contrast with the developed western countries indicates the contextual features of emerging economies where regulatory enforcement and normative pressure are still weak, and non-compliance of these dimensions may be a norm and, thus companies are able to seek legitimacy through active social involvements.

Environmental responsibility revealed four factors. According to factor loading, factor 4 (average loading .71) and the variable 'Independent verification of environmental performance by a government authority' ( $\mathrm{C} 8$ with .78 factor loading) are most important. This indicates the Indian managers strongly support government controlled environmental responsibility. The result indicates that Indian managerial attitudes towards CSER have significantly changed from what was traditionally perceived as foundation creation, public relation activity and philanthropic work. The change of Indian managerial attitude could be due to intense concern for economic growth, export-orientation, a tradition of government influence over business, strong family/community business structure and increased government legislations and regulations (Balasubramanian et al., 2005). The result helps to better understand the increased social responsiveness and changing attitudes towards CSER of the India managers. There is a strong belief that CSER is an essential element in 'social uplift' and development, something very relevant to a developing economy (India), but less emphasised in Western developed nations.

The mean responses to the CSER scale items (Table 4 \& 5) suggest a high level of support for social and environmental responsibility by Indian managers. These findings 
confirm the findings of Cummings (2008) where Chinese and Indonesian respondents were stronger than Australian respondents in their support of environmental issues. The mean response for the eight (B6, B8, B9 B13, C2, C4, C5 \& C8) items comprising the responsibility factor was approximately 4.1 for Indian managers on the five-point scale, indicating strong support for the general proposition that corporations and executives should be held accountable for the social and environmental impacts of their actions. The mean scores of CSER items reveal an overall positive attitude towards CSER amongst these groups of managers in India. The finding is in line with the findings of Kuasirikun (2005) which revealed an overall positive attitude towards CSER amongst the managers and accountingrelated professionals in another emerging economy (Thailand) and Islam and Dellaportas, (2011) in Bangladesh. Liangrong and Song (2009) and Tian et al., (2011) depicted a positive attitude towards CSER amongst Chinese managers. The findings also indicated that respondents were concerned about environmental responsibility, categorising few issues to be more important than other environmental factors. This result is also similar to the findings of another two studies of emerging economies (Kuasirikun, 2005; Liangrong \& Song, 2009), which found that managers were concerned about protection of the environment.

The standardised regression from Indian managerial attitude to social $(\beta=0.82$ at $\rho \leq 0.001)$ and environmental $(\beta=0.82$ at $\rho \leq 0.001)$ responsibility indicates that the Indian respondents consider social responsibility to explain higher percent of variance $(90 \%)$ in managerial attitude then environmental responsibility (82\%). The key driver of corporate responsibility comes from progressive entrepreneurship apply by managers and entrepreneurs. Evidence suggests that in the emerging countries, top managers still believe direct and major responsibility as moral actors navigating social responsibility choices of their organisations. This is so especially whilst external dynamics, such as regulatory capabilities and civil mobilization are still lacking in force. Moreover, managers in developing countries pursue CSER as a legitimacy-seeking strategy vis-a'-vis resource holders (Chen et al. 2010). Legitimacy is in the eyes of the beholder, making it an elusive quality, but it does not mean that firms cannot take steps that generate legitimacy (Suchman, 1995). To appear accountable most of the respondent in the sample do favour adopting responsible practices, such as international standards for an environmental management system, keeping records of greenhouse gas emissions, consultation with stakeholder groups when making environmental policy decisions.

Many of the global institutional forces create isomorphic pressures for a rise of explicit CSER; the extent to which explicit CSER will become more prevalent in the emerging countries still very much depends on the strengths of the institutional dynamics among cultural ethics, values, religion, and governments that have imprinted on the form and focus of CSER (Yin \& Zhang, 2012). Regarding CSER in a developing country context, the explanatory power of organisational legitimacy goes beyond its strategic tradition. Indian respondents exhibited that their cultural ethics and values have a strong influence on their attitudes towards responsibility. The institutional array of organisational legitimacy proves as a useful body of theory to inform CSER in a developing country context, since it is able to 
address cultural factors and goes beyond business case considerations (Bearkemeyer, 2007, p.15). The study demonstrate that responsibility and transparency as well as whether the company does its best in terms of social responsibility are highly significant for the evaluation of a company's legitimacy. Claasen and Roloff (2012) demonstrated that a link between legitimacy and responsibility of companies exists, but it is more complex than the link assumed by commonly used practices of reputation and stakeholder management. They commented that "Overall, organisational legitimacy is a complex social construction that is more resistant to manipulations by the focal organisation than, for example, company reputation and brand image which appear to be more reactive to cognitive and pragmatic influences. Organisational legitimacy, in contrast, is evaluated in moral terms; it results from a rational evaluation of the available information (p. 396). From the legitimacy theory perspective an organisation would provide information if management perceived that the particular information is demanded by the societies within which it operates. Overall positive managerial attitude towards CSER and increased response to the perceived importance of stakeholders demonstrated by the result reflect the applicability of organisational legitimacy theory.

\section{Conclusion, Implications \& limitations}

Indian managers strongly supported mandatory CSER reporting (factor loading .65). This finding also supports previous studies (CDCAC, 2002; Fukukawa, et al., 2007; Kuasirikun, 2005) that reported strong support for mandatory CSER reporting. This growing support for mandatory social and environmental reporting indicates that policy makers and regulatory authorities need to give serious consideration to mandatory CSER. As the driving force behind CSER in emerging economies is different (Belal \& Owen, 2007; Islam \& Deegan, 2008; Rahaman et al., 2004) from developed economy, mandatory CSER may push the emerging economies CSER in the next level.

\section{Practical Implications}

A number of practical implications both on the company and policy level can be derived from the study. From a company perspective, for Indian and so called Anglo-Saxon Western companies interested in social involvements in India, they must take into account how national institutional systems and cultural traditions influence local CSER patterns. CSER initiatives can lead to failure and therefore result in a misallocation of resources those do not match the local understanding of legitimacy. Companies' aimed-for goals will go beyond the company's capacity if an action is not perceived as relevant locally. As a result, companies who are pursuing a proactive approach to CSER can face situations in which a misallocation of (CSER) resources occurs through a different preconscious institutionalisation in home and host country (Barkemeyer, 2007). Corporate motivation within emerging economies could be somewhat different from that in developed economies. Rahaman et al. (2004); Belal \& Momin (2009) indicated that, unlike consumer pressure or pressure from NGOs or civil society groups, the driving force behind organisational CSER in emerging economies, which 
to a large extent depend on foreign loans and aid, could be external pressure from 'powerful' international lending institutions and parent company instructions and pressure from international buyers (Belal \& Owen, 2007; Islam \& Deegan, 2008). In order to gain a better understanding of the actual impact and local perceptions of the initiative more decentralised CSER structures and feedback loops can be vital for a CSER initiative. Economic growth is putting pressure on India's social and environmental issues. As India is an important emerging economy and future global market it is essential to know their managers and their attitudes toward society, practices of social and environmental well to accomplish business in India.

From a policy perspective, it is prudent to set measures in place that make sure a better integration and acknowledgement of various stakeholders. Feedback loops that strengthen the inter linkages between home and host country publics can reduce both the misallocation of resources of proactive companies and the tendency of reactive companies to employ CSER measures as a mere public relations tool (Barkemeyer, 2007). The underlying mechanisms of a predominantly voluntary CSER agenda within emerging economies could be somewhat different from that in developed economies so do not apply to a vast number of companies globally. Especially in the absence of structural framework conditions such as independent media or a conscious consumer base, it is unlikely that a critical mass can be reached that creates new, more sustainable behavioural norms, as e.g. envisioned by the UN Global Compact (see e.g. Kell, 2005: 72). Many of the Indian companies noted insufficient incentives from the regulatory framework, business climate, and consumer group. Thus, how to integrate various institutional elements into shaping the emerging CSER-related institutional system deserves consideration for policy makers in the emerging countries. In addition to delineating CSER by regulation, encouraging conducive normative institutional environment, providing training, and financial incentives to companies that take the lead in moving CSER forward, advocating for positive peer learning and punishing irresponsible behaviour, shaping consumer preferences in support of responsible business are all crucial in pushing forward CSER that is substantively implemented (Yin \& Zhang, 2012).

\section{Limitations}

The limitation of the study is that the questions used in the survey of this study do not represent the entire framework on which attitudes toward CSER of Indian managers are formed. Moreover, culture was not explicitly explored as a possible factor in the study. Little research has been undertaken so far on the association between social and environmental attitudes and culture. Future research could undertake further empirical research among various developed and emerging economies, and explore the principal cultural contexts that shape social and environmental values and attitudes in more detail.

\section{Referencs}


Adams, C. A., \& Kuasirikun, N. (2004). A comparative analysis of corporate reporting on ethical issues by UK and German chemical and pharmaceutical companies. European Accounting Review, 9(1): 53-79. http://dx.doi.org/10.1080/096381800407941

Arvidsson, S. (2010). Communication of Corporate Social Responsibility: A Study of the Views of Management Teams in Large Companies. Journal of Business Ethics, 96: 339 -354. http://dx.doi.org/10.1007/s10551-010-0469-2

Balasubramanian, N. K., Kimber, D., \& Siemensma, F. (2005). Emerging opportunities or Traditions Reinforced? An Analysis of the Attitudes towards CSR, and trends of Thinking about CSR, in India. Journal of Corporate Citizenship, 17 (Spring): 79-92. http://dx.doi.org/10.9774/GLEAF.4700.2005.sp.00010

Barkemeyer, R. (2007). Legitimacy as a Key Driver and Determinant of CSR in Developing Countries The 2007 Amsterdam Conference on the Human Dimensions of Global Environmental Change, 44: 1-23

Basu, K. \& Palazzo, G. (2008). Corporate social responsibility: A process model of sense making. Academy of Management Review, 33(1) 122-136. http://dx.doi.org/10.5465/AMR.2008.27745504

Belal A. R., \& Momin, M. (2009). Corporate Social Reporting (CSR) in Emerging Economies: A Review and Future Direction, Research in Accounting in Emerging Economics, 9: 119-145.

Belal, A. R., \& Owen, D. (2007). The Views of Corporate Managers on the Current State of, and Future Prospects for, Social Reporting in Bangladesh: An Engagement Based Study. Accounting, Auditing \& Accountability Journal, 20(3): 472-494. http://dx.doi.org/10.1108/09513570710748599

Bhattacharyya, A., \& Cummings, L. 2013. Attitudes Toward Environmental Responsibility within Australia and India: A comparative Study. Journal of Environmental Planning and Management. http://dx.doi.org/10.1080/09640568.2013.768972

Bitektine, A. (2011). Towards a theory of social judgments of organizations: The case of legitimacy, reputation, and status. Academy of Management Review, 36(1): 151-179. http://dx.doi.org/10.5465/AMR.2011.55662572

Canadian Democracy and Corporate Accountability Commission (CDCAC): 2002, The New Balance Sheet: Corporate Profits and Responsibility in the 21st Century, available at http://www.corporate-accountability.ca.

Carroll, A. B. (1999). Corporate social responsibility: Evolution of a definitional construct. Business and Society, 38(3) 268-295. http://dx.doi.org/10.1177/000765039903800303

Chen, J.C., \& Roberts, R.W. (2010). Toward a More Coherent Understanding of the Organisation-Society Relationship: A Theoretical Consideration for Social and Environmental Accounting Research. Journal of Business Ethics, 97: 651-665. http://dx.doi.org/10.1007/s10551-010-0531-0

Churchill, G. A. (1979). A paradigm for developing better measures of marketing constructs. Journal of Marketing Research, 16(1): 64-73. http://dx.doi.org/10.2307/3150876

Claasen, C. \& Roloff, J. (2012).The Link Between Responsibility and Legitimacy: The 
Case of De Beers in Namibia. Journal of Business Ethics, 107: 379-398. http://dx.doi.org/10.1007/s10551-011-1045-0

Coakes, S. J., Steed, L., \& Ong, C. (2010). SPSS: Analysis without Anguish. Milton, Qld: John Wiley \& Sons Australia Ltd.

Cummings, L. S. (2008). Managerial Attitudes Toward Environmental Management within Australia, the People's Republic of China and Indonesia. Business Strategy and the Environment, 18: 16-29. http://dx.doi.org/10.1002/bse.515

Dahlsrud, A. (2008). How Corporate Social Responsibility is Defined: An Analysis of 37 Definitions. Corporate Social Responsibility and Environmental Management, 15: 113. http://dx.doi.org/10.1002/csr.132

De Villiers, C. \& Van Staden, C. (2006). Can less environmental disclosure have a legitimizing effects? Evidence from Africa. Accounting, Organisation and Society, 31: 763-781. http://dx.doi.org/10.1016/j.aos.2006.03.001

Diamantopoulos, A. (2005). The C-OAR-SE procedure for scale development in marketing: A comment. International Journal of Research in Marketing, 22(1): 1-9. http://dx.doi.org/10.1016/j.ijresmar.2003.08.002

Dowling, J. \& Pfeffer, J. (1975). Organisational legitimacy: Social values and organisational behaviour. Pacific Sociological Review, 18(1): 122-136. http://dx.doi.org/10.2307/1388226

Eisenhardt, K. M. \& Graebner, M. E., (2007). Theory building from cases: opportunities and challenges. Academy of Management Journal, 50(1): 25-32. http://dx.doi.org/10.5465/AMJ.2007.24160888

Elkington, J. (1994). Towards the sustainable corporation: Win-win-win business strategies for sustainability. California Management Review, 36(2): 90-100. http://dx.doi.org/10.2307/41165746

Freeman, R. E., Harrison, J. S., Wicks, A. C., Parmar, B. L., \& de Colle, S. (2010). Stakeholder theory: The state of the art. Cambridge: Cambridge University Press. http://dx.doi.org/10.1017/CBO9780511815768

Fukukawa, K., Shafer W. E., \& Lee. G. M. (2007). Values and Attitudes Toward Social and Environmental Accountability: a Study of MBA Students. Journal of Business Ethics, 71: 381-394. http://dx.doi.org/10.1007/s10551-005-3893-y

Gray, R., Kouhy, R, \& Lavers, S. (1995a). Corporate social and environmental reporting: a review of the literature and a longitudinal study of UK disclosure. Accounting, Auditing \& Accountability Journal, 8(2): 47-77. http://dx.doi.org/10.1108/09513579510146996

International Code on Market and Social Research http://www.esomar.org/index.php/codesguidelines.html [05 April, 2008].

Islam, M. A., \& Deegan, C. (2008). Motivations for an organisation within a developing country to report social responsibility information: Evidence from Bangladesh. Accounting, Auditing \& Accountability Journal, 21(6): 850- 874. http://dx.doi.org/10.1108/09513570810893272

Islam, M. \& Dellaportas, S. (2011). Perceptions of corporate social and environmental accounting and reporting practices from accountants in Bangladesh. Social Responsibility Journal, 7(4): 649 - 664. http://dx.doi.org/10.1108/174711111111175191 
Jaggi, B., \& Zhao, R. (1996). Environmental Performance and Reporting: Perceptions of Managers and Accounting Professionals in Hong Kong. The International Journal of Accounting, 31(3): 333-346. http://dx.doi.org/10.1016/S0020-7063(96)90023-0

Jöreskog, K. G., \& Sörbom, D. (1996). LISREL 8: User's guide. Chicago: Scientific Software International.

Kell, G. 2005. The Global Compact. Selected Experiences and Reflections. Journal of Business Ethics, 59(1-2): 69-79. http://dx.doi.org/10.1007/s10551-005-3413-0

Kisenyi, V., \& Gray, R. (1998). Social disclosure in Uganda. Social and Environmental Accounting, 18(2): 16-18. http://dx.doi.org/10.1080/0969160X.1998.9651589

Koppell, J. G. S. (2008). Global governance organizations: Legitimacy and authority in conflict. Journal of Public Administration Research Theory, 18(2): 177-203. http://dx.doi.org/10.1093/jopart/mum041

Kuasirikun, N. (2005). Attitudes to the development and implementation of social and environmental accounting in Thailand. Critical Perspectives on Accounting, 16(8): 1035- 1057. http://dx.doi.org/10.1016/j.cpa.2004.02.004

Liangrong, Z., \& Song, L. (2009). Determinants of Managerial Values on Corporate Social Responsibility: Evidence from China. http://mpra.ub.uni-muenchen.de/8349/ MPRA Paper No. 8349, posted 20 April.

Lindblom, C. K. (1994). The Implications of Organisational Legitimacy for Corporate Social Performance and Disclosure. Paper Presented at the Critical Perspectives on Accounting Conference, New York.

Matten, D. \& Moon, J. (2008). "Implicit" and "explicit" CSR: A conceptual framework for a comparative understanding of corporate social responsibility. Academy of Management Review, 33(2) 404-424. http://dx.doi.org/10.5465/AMR.2008.31193458

Mitchael, J. H., Echols, A. E. \& Bukowski, S. (2010). Executive Perceptions of Adopting an Environmental Certification Program. Business Strategy and the Environment, 19: 466 - 478. http://dx.doi.org/10.1002/bse.665

Nunnally, J., \& Bernstein, I. (1994). Psychometric theory. New York: McGraw- ill.

Pachauri, R. K. (2006). CSR in new dimensions. The Economic Times.

Palazzo, G., \& Scherer, A. G. (2006). Corporate legitimacy as deliberation: A communicative framework. Journal of Business Ethics, 66(1): 71- 88. http://dx.doi.org/10.1007/s10551-006-9044-2

Petts, J., Herd, A., \& O'Heocha, M. (1998). Environmental Responsiveness, Individuals and Organisational Learning: SME Experience. Journal of Environmental Planning and Management, 41(6): 711-730. http://dx.doi.org/10.1080/09640569811380

Rahaman, A. S., Lawrence, S., \& Roper, J. (2004). Social and environmental reporting at the VRA: institutionalised legitimacy or legitimation crisis? Critical Perspectives on Accounting, 15(1): 35-56. http://dx.doi.org/10.1016/S1045-2354(03)00005-4

Raman, S. R. (2006). Corporate Social Reporting in India - A View from the Top. Global Business Review, 7(2): 313-324. http://dx.doi.org/10.1177/097215090600700208

Savage, G. T., Nix, T. W., Whitehead, C. J., \& Blair, J. D. (1991). Strategies for assessing and managing organizational stakeholders. Academy of Management Executive, 5(2): 61-75. http://dx.doi.org/10.5465/ame.1991.4274682 
Shafer, W. E. (2006). Social Paradigms and Attitudes Toward Environmental Accountability. Journal of Business Ethics, 65: 121-147. http://dx.doi.org/10.1007/s10551-005-4606-2

Stanaland, A. S., Lwin, M. O. \& Murphy, P.E. (2011). Consumer Perceptions of the Antecedents and Consequences of Corporate Social Responsibility. Journal of Business Ethics, 102: 47 - 55. http://dx.doi.org/10.1007/s10551-011-0904-z

Suchman, M.C. (1995). Managing legitimacy: strategic and institutional approaches. Academy of Management Review, 20(3): 571-610.

Thorne, L., \& Saunders, S. (2002). The Socio-Cultural Embededness of Individuals' Ethical; Reasoning in Organisations (Cross-cultural Ethics). Journal of Business Ethics, 35: 1-14. http://dx.doi.org/10.1023/A:1012679026061

Tian, Z., Wang, R. \& Yang, W. (2011). Consumer Responses to Corporate Social Responsibility (CSR) in China. Journal of Business Ethics, 101: 197 - 212. http://dx.doi.org/10.1007/s10551-010-0716-6

Williams, S., \& Pei, C. (1999). Corporate Social Disclosures by Listed Companies on Their Web Sites: An International Comparison. The International Journal of Accounting, 34(3): 389-419. http://dx.doi.org/10.1016/S0020-7063(99)00016-3

Xiao, J. Z., Gao, S. S., Heravi, S., \& Cheung, Y. C. (2005). The Impact of Social and Economic Development on Corporate Social and Environmental Disclosure in Hong Kong and the U.K. Advances in International Accounting, 18: 219-243. http://dx.doi.org/10.1016/S0897-3660(05)18011-8

Yakovleva, N. \& Vazquez-Brust, D. (2012). Stakeholder Perspectives on CSR of Mining MNCs in Argentina. Journal of Business Ethics, 106: 191 - 211. http://dx.doi.org/10.1007/s10551-011-0989-4

Yin, J. \& Zhang, Y. (2012). Institutional Dynamics and Corporate Social Responsibility (CSR) in an Emerging Country Context: Evidence from China. Journal of Business Ethics 111 (2):301-316 (2012). http://dx.doi.org/10.1007/s10551-012-1243-4 